\title{
Society Empowerment through Ecotourism
}

\author{
$1^{\text {st }}$ Siti Hafsah Budi Argiati \\ Universitas Sarjanawiyata \\ Tamansiswa Yogyakarta \\ Indonesia \\ Yogyakarta, Indonesia \\ $4^{\text {th }}$ Nonik Kusuma Ningrum \\ Universitas Sarjanawiyata \\ Tamansiswa Yogyakarta \\ Indonesia \\ Yogyakarta, Indonesia \\ nonik.kusumaningrum@ustjog \\ ja.ac.id
}

\author{
$2^{\text {nd }}$ Henny Welsa \\ Universitas Sarjanawiyata \\ Tamansiswa Yogyakarta \\ Indonesia \\ Yogyakarta, Indonesia
}

\author{
$3^{\text {rd }}$ Ari Astuti \\ Universitas Sarjanawiyata \\ Tamansiswa Yogyakarta \\ Indonesia \\ Yogyakarta, Indonesia
}

\begin{abstract}
This research is aimed to explore tourism potential of mangrove forest in Indonesia costal area and expected to be the foundation of national strategic policy, specifically in strengthening costal area national economics. The object of this research is the society around mangrove forest in costal area. Purposive sampling is used as sampling technique. Sample size of this research is $\mathbf{1 0 0}$ samples. PLS is utilized as data analitical tool. This research is focus on poverty alleviation through ecotourism that has not been developed. Economic strengthening in costal area is important because Indonesia is a maritim country, which means that most of Indonesia society make living depending on the sea. Therefore, digging the potential of ecotourim to increase society income has became national strategic issue which has multiplier effects. Policy proposal on mangrove forest costal area economics strenghtening especially in Dumai Riau Indonesia is expected to be the outcome of this research. Successful implementation of this policy is expected to be the source of reference for other Indonesia costal areas because Dumai has the most complete species in compare with other area. As conclusion, the output of this research is expected to contribute to the improvement of Indonesia national economics.
\end{abstract}

Keywords: ecotourism, mangrove forest, costal area

\section{INTRODUCTION}

Tourism has been proven escalating society life. This sector can move the wheels of economy in all walks of life and improve society welfare, as well as pulls the district growth and development. This is in line with the national development growth paradigm which emphasizes the attempt of society development based on three pillars orientations including pro job, pro poor, and pro growth.

Indonesia is the biggest archipelagic country in the world with more than 17.508 archipelagos and more than $99.000 \mathrm{~km}$ coastline which stretches from Sabang to Maurauke which means that Indonesia has a high potential on marine tourism. One of a kind of marine tourism potential which is now in a great demand is mangrove forest ecotourism. International Ecotourism Society defines ecotourism as responsible travel to natural areas that conserves the well-being of local people [1] .

Dumai (Riau) mangrove forest is classified as the most complete mangrove species in Indonesia. Located in a wide area with more than 22 acres along the coastline, this region is developing as one of the leading ecotourism spots in Dumai. However, society around mangrove forest have not received significant impact on their economy. Therefore, the development of the society around mangrove forest coastal area in Dumai is expected to improve their business capability and income. 


\section{A. LITERATURE REVIEW.}

Ecotourism. Ecotourism is a kind of tourism that closely related to conservation principle, and also an appropriate and efficient way in maintaining the authenticity of ecosystem, even the quality of the preservation of the nature can be improved [2]. Ecotourism can be potentially used to 1) develop economics opportunities, 2) protect natural resources and cultural value, and 3) improve the quality of life [3].

Empowerment. Empowerment is a process changing individual or organization or group who are in a state of powerless become aware of the dynamics of power which is working in their life, building the skills and capacity to gain advantage in their life without disrupting the right of others [4].

Capabilities. Capabilities refer to company skills in coordinating resources and allocate it for productive use. Capabilities have a significant roles to create company performance [5]. Even though company has valuable and unique resources, but they do not have capabilities to effectively utilize the resources, company will not be able to maintain long-term capabilities, therefore capability is an important strategy that contribute to the sustainable competitive advantage [6].

Income. According to [7], tourism activities can increase 1) community and government revenue through tourists expenses and costs of staying; and 2) business opportunities and jobs through the demands of souvenirs, homestays, hotels, tourist guides etc.

\section{B. HYPOTHESES DEVELOPMENT}

Research on ecotourism in Bandar Bakau Dumai Riau which is conducted [8] found that Bandar Bakau has been used as natural resources protection area however benefits obtained by the society are still lacking and good governance is still needed. Therefore, this research formulate hypothesis as follow: ecotourism and society empowerment through business capability are significantly positive affect society income.

II. RESEARCH METHODS

This research involves 2 (two) independent variables consist of ecotourism
(X1) and society empowerment (X2); 1 (one) dependent variable, income (Y1); and 1 (one) mediating variable, business capabilities (Z1). This research population are society around mangrove forest costal area. Samples of this research are society around mangrove forest of five region in Dumai (Riau). A number of 100 respondents were asked to fill in the questionnaire. Purposive random sampling was utilized as sampling technique, as for respondent requirements are only those who have been living around mangrove forest area and received benefits from this area are eligible to fill in the questionnaire.

\begin{tabular}{|c|c|c|c|}
\hline \multicolumn{4}{|c|}{ Ecotourism } \\
\hline No & Participation & Score & Average \\
\hline 1 & $\begin{array}{l}\text { Government } \\
\text { involves me in all } \\
\text { activities related to } \\
\text { mangrove forest }\end{array}$ & 145 & 1,45 \\
\hline 2 & $\begin{array}{l}\text { Society around } \\
\text { mangrove forest is } \\
\text { independently } \\
\text { participate in all } \\
\text { activities related to } \\
\text { mangrove forest }\end{array}$ & 227 & 2 \\
\hline 3 & $\begin{array}{l}\text { I participate in all } \\
\text { mangrove forest } \\
\text { activities as tourism } \\
\text { site }\end{array}$ & 220 & 2,2 \\
\hline & Total & 592 & 1.97 \\
\hline
\end{tabular}

\begin{tabular}{|c|l|c|c|}
\hline No & Conservation & Score & Average \\
\hline 1 & $\begin{array}{l}\text { I actively participate } \\
\text { in mangrove } \\
\text { conservation }\end{array}$ & 216 & 2,16 \\
\hline 2 & $\begin{array}{l}\text { Government } \\
\text { actively conservates } \\
\text { mangrove forest }\end{array}$ & 190 & 1,9 \\
\hline 3 & $\begin{array}{l}\text { Conservation leads } \\
\text { to sustainable nature }\end{array}$ & 380 & 3,8 \\
\hline 4 & $\begin{array}{l}\text { Conservation avoids } \\
\text { rob flood }\end{array}$ & 362 & 3,62 \\
\hline & Total & 1148 & 2.87 \\
\hline
\end{tabular}




\begin{tabular}{|c|l|c|c|}
\hline \multicolumn{3}{|l|}{ Society Empowerment } \\
\hline No & $\begin{array}{l}\text { Livelihood } \\
\text { development }\end{array}$ & Score & Average \\
\hline 1 & $\begin{array}{l}\text { I have chances to } \\
\text { get training to make } \\
\text { use of mangrove } \\
\text { forest }\end{array}$ & 170 & 1,7 \\
\hline 2 & $\begin{array}{l}\text { I have chances to } \\
\text { get training outside } \\
\text { my livelihood } \\
\text { related to mangrove } \\
\text { forest }\end{array}$ & 166 & 1,66 \\
\hline 3 & $\begin{array}{l}\text { I have other job } \\
\text { besides my main job }\end{array}$ & 248 & 2,48 \\
\hline & Total & 584 & 1.95 \\
\hline
\end{tabular}

\begin{tabular}{|c|l|c|c|}
\hline No & $\begin{array}{l}\text { Market access } \\
\text { development }\end{array}$ & Score & Average \\
\hline 1 & $\begin{array}{l}\text { It is easy to market } \\
\text { my production }\end{array}$ & 291 & 2.91 \\
\hline 2 & $\begin{array}{l}\text { I ever get training } \\
\text { assistance to sell my } \\
\text { production }\end{array}$ & 138 & 1,38 \\
\hline 3 & $\begin{array}{l}\text { Production outcome } \\
\text { is directly sell to } \\
\text { customer }\end{array}$ & 276 & 2,76 \\
\hline 4 & $\begin{array}{l}\text { Production outcome } \\
\text { is need to be } \\
\text { proceed before } \\
\text { selling }\end{array}$ & 143 & 1,43 \\
\hline & Total & 848 & 2.12 \\
\hline
\end{tabular}

\begin{tabular}{|c|l|c|c|}
\hline No & $\begin{array}{l}\text { Capital access } \\
\text { development }\end{array}$ & Score & Average \\
\hline 1 & $\begin{array}{l}\text { Finance factor/ cost } \\
\text { is the main obstacle } \\
\text { to develop business }\end{array}$ & 370 & 3,7 \\
\hline 2 & $\begin{array}{l}\text { I get capital } \\
\text { assistance from } \\
\text { government }\end{array}$ & 155 & 1,55 \\
\hline 3 & $\begin{array}{l}\text { I get capital } \\
\text { assistance from } \\
\text { private party }\end{array}$ & 125 & 1,25 \\
\hline 4 & $\begin{array}{l}\text { I get loan from the } \\
\text { bank for my job }\end{array}$ & 121 & 1,21 \\
\hline & Total & 771 & 1.93 \\
\hline
\end{tabular}

\begin{tabular}{|c|l|c|c|}
\hline No & $\begin{array}{l}\text { Collective action } \\
\text { development }\end{array}$ & Score & Average \\
\hline 1 & $\begin{array}{l}\text { I am a member of } \\
\text { cooperation in my } \\
\text { working } \\
\text { environment }\end{array}$ & 129 & 1,29 \\
\hline 2 & $\begin{array}{l}\text { As a member of } \\
\text { cooperation I get } \\
\text { benefits } \\
\text { economically }\end{array}$ & 136 & 1,36 \\
\hline & Total & 265 & 1.325 \\
\hline
\end{tabular}

\begin{tabular}{|c|l|c|c|}
\hline No & $\begin{array}{l}\text { Technology access } \\
\text { development }\end{array}$ & Score & Average \\
\hline 1 & $\begin{array}{l}\text { I get training to use } \\
\text { technology in my } \\
\text { job }\end{array}$ & 132 & 1,32 \\
\hline 2 & $\begin{array}{l}\text { I get counseling to } \\
\text { use technology in } \\
\text { my job }\end{array}$ & 144 & 1,44 \\
\hline 3 & $\begin{array}{l}\text { I have used latest } \\
\text { technology in my } \\
\text { job }\end{array}$ & 157 & 1,57 \\
\hline & Total & 433 & 1.45 \\
\hline
\end{tabular}




\begin{tabular}{|c|l|c|c|}
\hline \multicolumn{3}{|l|}{ Business capability variables } \\
\hline No & $\begin{array}{l}\text { The ability to } \\
\text { provide raw } \\
\text { materials }\end{array}$ & Score & Average \\
\hline 1 & $\begin{array}{l}\text { It is easy to get raw } \\
\text { materials that is } \\
\text { needed in my } \\
\text { production }\end{array}$ & 209 & 2,09 \\
\hline 2 & $\begin{array}{l}\text { It is easy to provide } \\
\text { raw materials in } \\
\text { time as it is needed }\end{array}$ & 209 & 2,09 \\
\hline 3 & $\begin{array}{l}\text { I have a good } \\
\text { relationship with the } \\
\text { supplier therefore } \\
\text { we do not have any } \\
\text { obstacle to get raw } \\
\text { materials }\end{array}$ & 204 & 2,04 \\
\hline & Total & 622 & 2.07 \\
\hline
\end{tabular}

\begin{tabular}{|c|l|c|c|}
\hline No & Product quality & Score & Average \\
\hline 1 & $\begin{array}{l}\text { Product is based on } \\
\text { customer needs and } \\
\text { has a good } \\
\text { competitive } \\
\text { advantage }\end{array}$ & 243 & 2,43 \\
\hline 2 & $\begin{array}{l}\text { Product is based on } \\
\text { market taste }\end{array}$ & 233 & 2,33 \\
\hline & Total & 476 & 2.38 \\
\hline
\end{tabular}

\begin{tabular}{|c|l|c|c|}
\hline No & Price & Score & Average \\
\hline 1 & The price is suitable & 272 & 2,72 \\
\hline 2 & $\begin{array}{l}\text { Alternatives based } \\
\text { on pricing is being } \\
\text { evaluated }\end{array}$ & 163 & 1,63 \\
\hline & Total & 435 & 2.175 \\
\hline
\end{tabular}

\begin{tabular}{|c|l|c|c|}
\hline No & Employee & Score & Average \\
\hline 1 & $\begin{array}{l}\text { It is easy to get } \\
\text { employee }\end{array}$ & 257 & 2,57 \\
\hline 2 & $\begin{array}{l}\text { Employee is } \\
\text { recruited from } \\
\text { family }\end{array}$ & 255 & 2,55 \\
\hline 3 & $\begin{array}{l}\text { Payment system is } \\
\text { based on regional } \\
\text { payment standard }\end{array}$ & 205 & 2,05 \\
\hline & Total & 717 & 2.39 \\
\hline
\end{tabular}

\begin{tabular}{|c|l|c|c|}
\hline No & Product variation & Score & Average \\
\hline 1 & $\begin{array}{l}\text { Often offering new } \\
\text { product }\end{array}$ & 161 & 1,61 \\
\hline 2 & $\begin{array}{l}\text { Products sell is more } \\
\text { than one kind }\end{array}$ & 232 & 2,32 \\
\hline & Total & 393 & 1.965 \\
\hline
\end{tabular}

\begin{tabular}{|c|l|c|c|}
\hline No & $\begin{array}{l}\text { Production } \\
\text { technology that is } \\
\text { used }\end{array}$ & Score & Average \\
\hline 1 & $\begin{array}{l}\text { The development of } \\
\text { technology } \\
\text { influences my } \\
\text { business } \\
\text { development }\end{array}$ & 155 & 1,55 \\
\hline 2 & $\begin{array}{l}\text { The equipment used } \\
\text { in business is in } \\
\text { accordance with } \\
\text { technological } \\
\text { development }\end{array}$ & 174 & 1,74 \\
\hline & Total & 329 & 1.645 \\
\hline
\end{tabular}

\begin{tabular}{|c|l|c|c|}
\hline No & Market Reach & Score & Average \\
\hline 1 & $\begin{array}{l}\text { The main buyer is } \\
\text { from the } \\
\text { surrounding area }\end{array}$ & 230 & 2,30 \\
\hline 2 & $\begin{array}{l}\text { Market reach } \\
\text { including mangrove } \\
\text { forest district }\end{array}$ & 231 & 2,31 \\
\hline & Total & 461 & 2.305 \\
\hline
\end{tabular}

\begin{tabular}{|c|l|c|c|}
\hline No & The easiness to buy & Score & Average \\
\hline 1 & $\begin{array}{l}\text { Buyer is directly } \\
\text { buy from the } \\
\text { merchant }\end{array}$ & 310 & 3,10 \\
\hline 2 & $\begin{array}{l}\text { The location is easy } \\
\text { to reach }\end{array}$ & 308 & 3,08 \\
\hline & Total & 618 & 3.09 \\
\hline
\end{tabular}




\begin{tabular}{|c|l|c|c|}
\hline No & $\begin{array}{l}\text { The availability of } \\
\text { capital }\end{array}$ & Score & Average \\
\hline 1 & $\begin{array}{l}\text { Capital assistance is } \\
\text { from the bank }\end{array}$ & 117 & 1,17 \\
\hline & Total & 117 & 1.17 \\
\hline
\end{tabular}

\begin{tabular}{|c|l|c|c|}
\hline \multicolumn{3}{|l|}{ Income } \\
\hline No & Item & Score & Average \\
\hline 1 & $\begin{array}{l}\text { My family income } \\
\text { lomes from the } \\
\text { activities in } \\
\text { mangrove }\end{array}$ & 246 & 364 \\
\hline 2 & $\begin{array}{l}\text { Mangrove tourism } \\
\text { will increase my } \\
\text { income. }\end{array}$ & 353 & 3,53 \\
\hline 3 & $\begin{array}{l}\text { Mangrove forest as } \\
\text { tourism sites will } \\
\text { provide job } \\
\text { opportunities for my } \\
\text { family }\end{array}$ & 392 & 3.92 \\
\hline & Total & 991 & 3.30 \\
\hline
\end{tabular}

This paper is a preliminary research result to be presented in conference to gain more inputs from peers review. Research findings will be discussed based on the lowest average score to find out what are the main problem of the society around mangrove forest.

Ecotourism variable. This variable consists of participation and conservation dimensions. In participation dimension, respondents stated that government does not involved them in all activities related to mangrove forest area; and in conservation dimensions, it is stated that government does not actively take roles in mangrove forest conservation.

Society empowerment. This variable is consists of livelihood development, capital access development, technological access development, market access development, and collective action development. As stated in livelihood development dimension, the average respondents said that they never get any training related to mangrove forest for their side income. In capital access development dimension, respondent stated that they did not get loan from the bank. Related to technology access development, they did not get any training to use technology in their job. In market access development dimension, they said that the never get any training assistance to sell their production outcome. Finally, from collective action development, the average respondents said that they are not members of any cooperation in their environment.

Business capability variable. This variable consists of the ability to provide raw materials, employee, production technology used, product quality, price, product variation, market reach, the easiness to buy, and the availability of capital dimensions. According to the availability to provide raw materials, most of them does not have a good relationship with the suppliers, therefore they have an obstacle to get raw materials. As stated in employee dimension, most of the respondent said that their payment system is not based on regional payment standard. Related to production technology, the average respondent said that the development of technology does not influence their business development. In production quality dimension, the average respondents stated that their product is not based on market taste. As in price dimension, it is stated that respondents said that there are no evaluation related to alternatives. Based on product variation dimension, it is stated that they are not often offering new product. In market reach dimensions, shows that the main buyer of their product is not only in their surrounding environment. As stated on the easiness to buy dimension, their location is not easy to reach. Last, as stated in the availability of the capital, there are no capital assistance from the bank.

Income variable. The average respondents express that their family income is not coming from their activity in mangrove forest area.

\section{CONCLUSION}

The involvement of government in ecotourism activities is still very low, almost all activities are carried out independently by the society. The society has not received capital assistance from the government or banking. The society can not fully rely on its main income in ecotourism activities. The community believes that this mangrove forest ecotourism development will open new opportunities for the community 


\section{REFERENCES}

[1] C. T. Karubaba, D. G. Bengen, and V. P. . Nikijuluw, "Kajian Pemenuhan Kebutuhan

Pangan Nelayan Pada Musim Timur dan Musim

Barat Kaitannya dengan Pemanfaatan

Sumberdaya Pesisir," Pesisr dan Lautan, vol. 3, no. 3, pp. 1-11, 2001.

[2] C. Fandeli, "Pengertian dan Konsep Dasar Ekowisata," Society, no. 1990, pp. 1-5, 2000.

[3] A. Tuwo, Pengelolaan ekowisata pesisir dan laut: pendekatan ekologi, sosial-ekonomi. kelembagaan, dan sarana wilayah. Brilian Internasional, 2011.

[4] L. G. L. K. Dewi, "Usaha Pemberdayaan Sosial Ekonomi Masyarakat Desa Beraban dalam Pengelolaan Tanah Lot secara Berkelanjutan," vol. 13 , no. $1,2013$.

[5] J. R. G. Charles, Hill. W.L. Charles and Gareth, "Strategic_Management_An_Integrated_Appro. ".

[6] G. S. Day, "The of Market-Drive Capabilities Organizations," J. Mark., vol. 58, no. 4, pp. 37 52, 1994

[7] F. Rahayu, "Analisis pengaruh sektor pariwisata terhadap perekonomian kota bogor,” 2006.

[8] R. Helvina, "Ekowisata Mangrove sebagai Kawasan Perlindungan Sumberdaya Alam dan Nilai Budaya di Bandar Bakau Kota Dumai," vol. 2, no. 1, pp. 1-11. 